\title{
Immortality: The probable future of human evolution
}

\author{
B. Lalruatfela \\ Department of Zoology, Mizoram University, Aizawl 796004, Mizoram, India
}

\begin{abstract}
Life and death is a natural phenomenon. Human have longed to be immortals and this is reflected in the beliefs of most, if not all, religions. In this article, brief overview of some of the immortal biological systems, both at the cellular and organismal levels are highlighted. Assumptions of the author on immortality and the probable future of human evolution are also discussed.
\end{abstract}

Key words: Cancer, HeLa, immortality, mortality, telomerase, Turritopsis dohrnii.

\section{Received 17 February 2017 Accepted 20 March 2017}

*For correspondence $\square$ : b.atetea@gmail.com

Contact us $\bowtie$ sciencevision@outlook.com

\section{Introduction}

Much the same as life, death is a natural phenomenon. In fact, every living entity, including the being writing this article and the one reading the same will one day be clenched by the frosty hands of the grim reaper. It is perplexing to imagine consequences after death. Is it just darkness? Or is there life after death as in most religious beliefs? This uncertainty of event possibly led humankind to desire immortality of our current physical form. A state where our mind can predict, although very inaccurately, what might occur. And yes consider this, "What if we cannot die?" Difficult to imagine, isn't it? It may be incomprehensible for many of us to ideate life without death; that is to live for eternity. Possibly because the lifespan of our species is in general less than a century, evolution might have shaped our intellect to consider only such a limited scale of time.

It would be very possible to provoke philoso- phical arguments on what constitute mortality and immortality, so, let us try to be more scientific than be philosophical. Now let us give an effort to understand what mortality and immortality biologically means. Hayflick defined biological mortality as "the death of an organism or the termination of its lineage" and immortality as "the indefinite survival of a single organism or of a replicating population regardless of molecular turnover". ${ }^{1}$ Thus, in the current context, we shall turn our interest to the level of both single organisms and on replicating populations.

Many stories and tales throughout ages had depicted great number of individuals who were deemed immortals. Say for example the Greek gods like Zeus, Poseidon, Hades, etc., and the rather infamous Count Dracula, the vampire who, in stories was known to feed on hominids aqueous physiological constituents comprising of erythrocytes, leukocytes, thrombocytes, plasma and others; or more simply, blood. Well, the point is these are the immortal beings in such 
tales. The influence of superheroes and mythological figures on our psychological construct is so immense that very often one desires to be immortal. It is amazing to learn that many young beings wished to become the Marvel superhero, Wolverine, of X-Men, perhaps because of his regenerative ability. Come on, if a bullet or an atom bomb can't terminate your existence on Earth, how cool would that be? But, young readers of this article must be warned with much regret that he is only a beloved fictitious character of the entertainment industry. Oh! Don't be disheartened so hastily. You are about to read accounts of non-fictitious biological immortals, indeed, the real deal of life. Let us begin without a backbone.

\section{The Transparent Immortals}

The seahorse (Hippocampus sp.) looks like a limbless horse (Equus ferus), but a jellyfish does not look anything like members of the class Pisces. Perhaps, many of us have heard and seen a jellyfish, in real life or at least on papers or digital graphics. They are free swimming aquatic animals found in every ocean, from the surface to

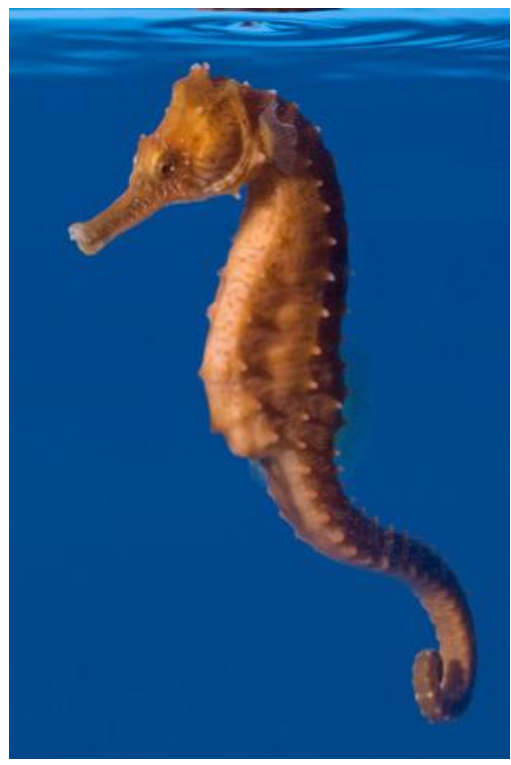

Figure 1 | A seahorse (Hippocampus). the depth of seas. They belong to the phylum Cnidaria and have a somewhat gelatinous domeshaped body with varying numbers of protruding posterior tentacles. Their transparent body color somehow looks harmless. They look harmless alright, but looks can often be very deceptive! Their tentacles can be used for capturing prey or as a defense against invading predators by discharging toxins that cause excruciating pain to the victims. ${ }^{2}$

The life cycle of a typical jellyfish may be divided into two phases, sexual and asexual. In the sexual phase they are motile and in the asexual phase, they are not. The sperm and egg from solitary, sexual adult jellyfishes called medusae (sing. medusa) fertilized and developed into an embryo that further developed into planula larva. The planula larvae formed a colonial polyp. The solitary sexual medusa are formed asexually from the colonial polyp. These medusae have

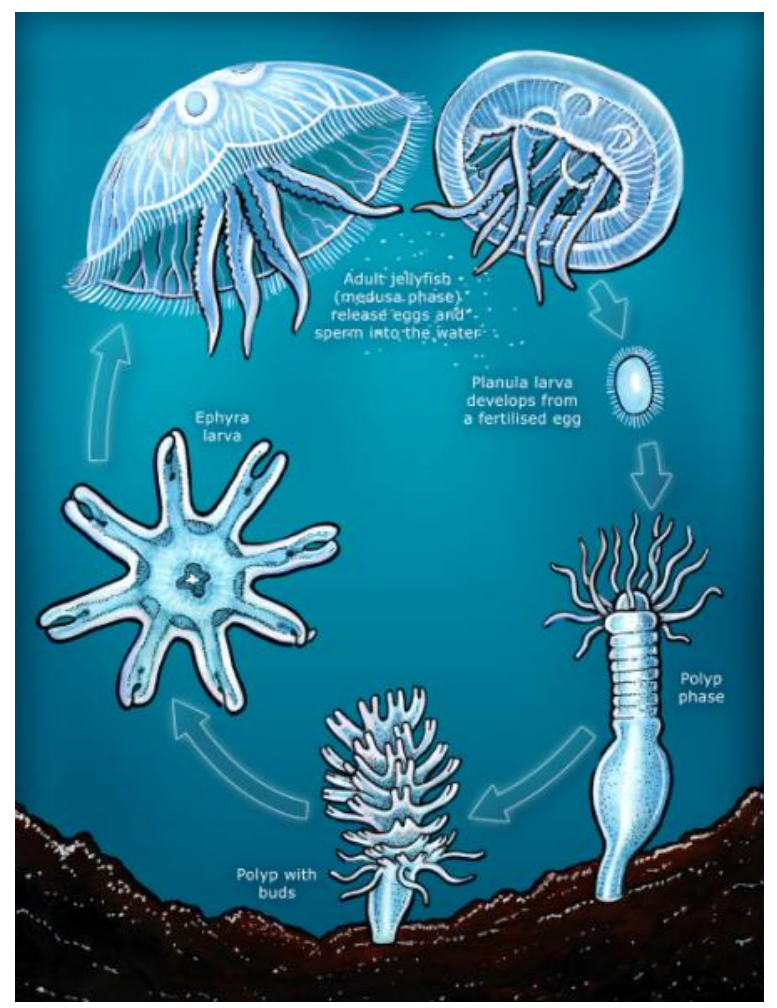

Figure 2 | Life cycle of jellyfish. 
limited lifespan and usually die shortly after fertilization. $^{3}$

However, a not so typical jellyfish species called Turritopsis dohrnii (formerly classified as Turritopsis nutricula) have the ability to skip the "death" part of their lifecycle. Of course they can die the old fashion ways, like being eaten by other predators. But when they faced physical damage, starvation or stress, they can revert back to their baby form, i.e. polyp stage, by a process called transdifferentiation, and start their life cycle all over again, with no change in their genetic composition, hence, they are essentially the same individual. ${ }^{4,5}$ In transdifferentiation, mature somatic cells get transformed into another whole new type of cells. In simple terms, it's like the liver cells becoming the skin cells. ${ }^{6}$ This amazing life reversal ability of this particular jellyfish has been observed in both wild and the laboratory, so, technically they are immortals. ${ }^{7}$ If

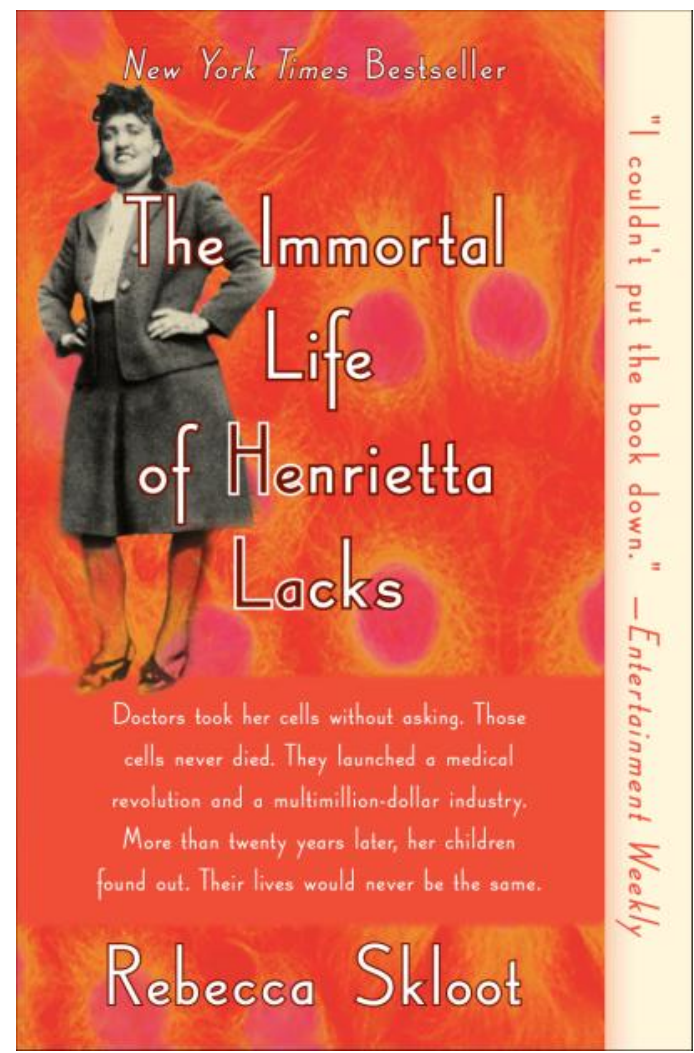

Figure 3 | Biography of Henrietta Lacks. you were offered the choice, to revert back to baby, just moments before you inhale your last breath, will you take it? I might, if I am allowed to keep my diaries.

\section{Illustrious Lady}

This ordinary lady is astounding and immortal, figuratively in a way. She may be considered both dead and alive (this sounds like Schrödinger's cat!). Let me elucidate the point. If we consider life of an individual at the organismal level, she is indeed, very dead. But if we consider it at the cellular level, she is still very much alive. She, in fact her cells, do not require any introduction among biologists. But for those of us who might still be in the dark let me introduce to you Mrs. Henrietta Lacks, more famously known as HeLa, of the HeLa cell line.

She was also known by the name Helen Lane or Helen Larson, but her real name is in fact, Henrietta Lacks. Amazingly, her birth name is Loretta Pleasant, but no one knows how she became Henrietta Lacks. By today's terminology, she will be referred to as an African-American, or simply Black. On $29^{\text {th }}$ January, 1951, after experiencing abnormal vaginal bleeding and a feeling of "knot" in her womb for some time, Henrietta went to John Hopkins Hospital (Baltimore, Maryland, USA) gynecology ward where she was examined by Dr. Howard Jones and was diagnosed with epidermoid carcinoma of the cervix. Dr. Lawrence Wharton Jr. took samples from her and sent them to Dr. George Gey for tissue culture. Gey had spent around thirty years of his professional life trying to grow human cancer cells outside the body but failed repeatedly. After the second day of inoculating Henrietta's cells into the culture tubes, their laboratory attendant Mary Kubicek found that the tubes containing HeLa cells were overcrowded and had to make subcultures. The amazing part of this story is that Henrietta had never been given credit for her important contribution to cell line culture and she had no knowledge of her contribution till her death on $4^{\text {th }}$ October, 1951. Even her relatives, for a long period, had no awareness of the con- 
tributions of HeLa cells to the scientific community and eventually humanity. Only after twenty five years Henrietta's husband, Day Lacks received a call from $\mathrm{Dr}$. Susan $\mathrm{Hsu}$, a geneticist from Baltimore and thus, learnt about the existence of his wife's cells. ${ }^{8,9}$

She, more precisely her cells, participated in many inconceivable scientific experiments and expeditions. Believe it or not she went to space; was in a nuclear explosion; infected with polio by Jonas Salk in search of its vaccine; participated in AIDS study, gene mapping, etc. HeLa cells were the first human cells to be successfully cloned in 1955. After more than half a century of Henrietta's death, more than 50 million metric tons of her cells have been grown and continue to occupy countless laboratories throughout the world. Her contribution to science and humanity is enormous, may be more than any individual
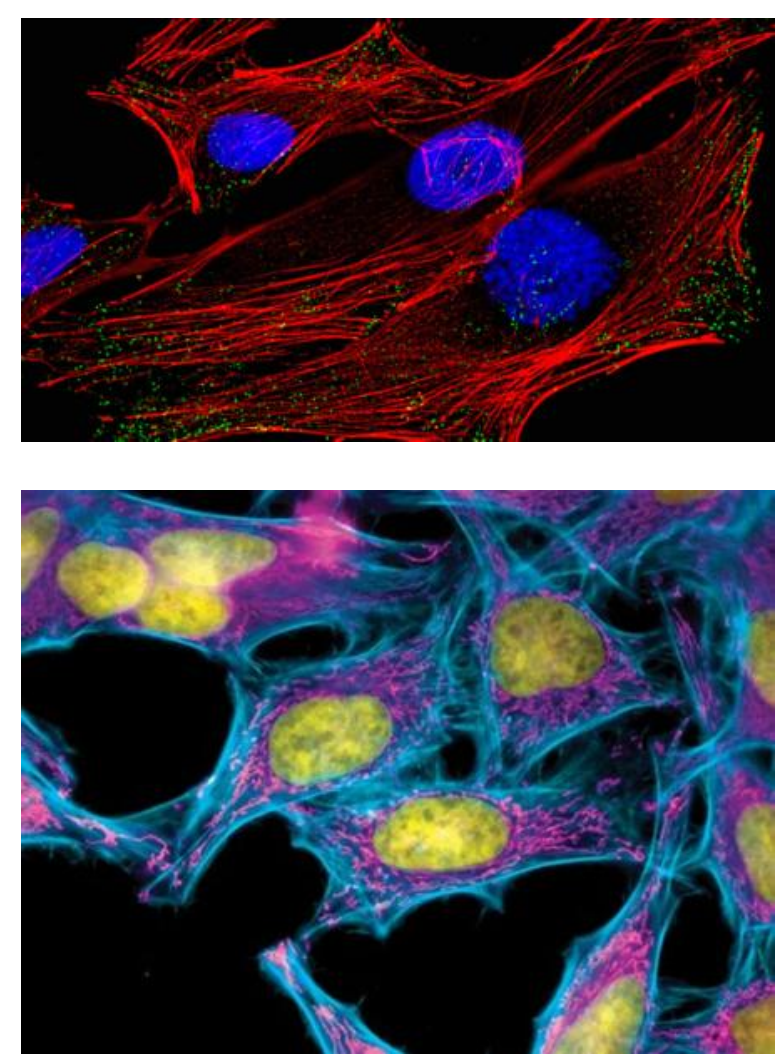

Figure 4 | The living Henrietta Lacks, HeLa cells. human being that ever roamed the Earth. ${ }^{10,11}$

\section{Oh Crab!}

One of the most bewildering and common disease that killed billions throughout the ages is cancer. The word cancer is a latin word, a literal translation of which is "crab". The Father of Medicine, Hippocrates after investigating a particular form of illness gave a Greek name for that disease, karkinos. Aulus Cornelius Celsius literally latinized karkinos and called it cancer. A standard definition of cancer might be "a disease in which a group of abnormal cells grow uncontrollably by disregarding the normal rules of cell division resulting in more or less immortal cells". ${ }^{12}$ Like all other diseases its cure has been pursuit, but in this case, not with definite success. There are treatments that kill cancerous cells and extending the lives of the victims. But a perfect cure has never been found and whether or not it will be found is a million dollar question. $^{13}$

Here is a crazy thought. What if cancer is a good disease? In your head chemical reactions took place and neurons released neurotransmitters from pre-synaptic to post-synaptic cells and asked "A good disease? Are you crazy?" It is most explicable if you are startled and thought that I am crazy, the warning sign is right up there. Allow me, once again to elaborate. Medically speaking, absolutely, cancer is a disease that kills. But, evolutionarily speaking it seems to be an error in a trial of immortality. It seems nature has found a way to attain immortality at the cellular level, I assume that sometimes in the future nature will find a way to attain immortality at an individual level. It might just be nature rolling the dice; a gambling for life.

I hope an addition of a few lines of my conception would not hamper the scientific sentiment of this article. If we think of cells as individual beings, our concept of cancer as nature's way of attaining immortality may be more welldefined. Maybe this story will enlighten you, or at least amused you. One day a fine young celllady residing in the antrum of the stomach fortu- 
nately discovered the ability to 'not' die and then started a cellular gossip. As human (an assemblage of cells) loves gossip, so do the cells. So, the genius cell-lady who had the Nobel prize winning discovery told every cells in her community, in this case the stomach, her trick of evading death. So, all of them decided not to die. Cells not dying is in fact the definition of cancer and voila, we have a stomach cancer. It is a remarkable quality of living organisms to try and survive even when survival means destruction to our environment. Likewise, the cancer cells cannot comply with their surroundings, their improvement causes havoc to their environments. Actually, we may and should not blame them for acting so out of line because even we, human, fail to comprehend the disaster we generated to our environments and yet we claimed to climb highest in the evolutionary tree. Maybe we are not so far along. It may be fortunate for the cells to attain immortality but definitely not for the persons owning the immortal cells. It is rightly a cellular fortune, but an individual's damnation.

My notion is that cancer is a disease and an improvement. If we could be choosey and eliminate certain key characters of cancerous cells, like their ability to divide incessantly and their abnormal cellular membrane and stick only to their ability to evade apoptotic signals, we may be able to create an organism that neither die nor age. Evolution is often regarded as a nonreversible process, ${ }^{14}$ so, if cancer is a step in cellular evolution as I have assumed, there may never be a perfect cure of cancer, forgive me if I am too pessimistic. Of course killing the cells is a different story. If all cancerous cells died, there may be no potential way for the organism to survive, especially in high stage cancer where majority of the body's cells are cancerous.

\section{Tail of Life}

The life cycle of most known organisms involve aging or senescence. ${ }^{15}$ Taking human as an example, after a certain age, say fifty, symptoms of aging start to appear. This include weakness of the bones and muscles, wrinkles, gray hairs, decrease visual acuity, etc. It is obvious that after sometime, our cells loss their ability to divide, a point called Hayflick limit. ${ }^{16}$ The answer why cells reach the Hayflick limit lie in phenotypic blueprint.

Eukaryotes have chromosomes consisting of double stranded linear deoxyribonucleic acid (DNA). However, the end region of the chromosome is a single non-coding tandemly repeated sequence. This region of the chromosome is called the "telomere" and was independently discovered in the 1930s by two scientists, Barbara McClintock and Herman Muller. ${ }^{17}$ The human telomeric sequence is $5^{\prime}$-TTAGGG-3' that vary from 2 to 50 kilo base pairs and a G-tail of 100-250 bases extending from double stranded to the single stranded region. This single stranded G-rich telomere acts with other proteins to form a T-loop structure serving a protection to the chromosome and maintaining genomic stability. Otherwise, the end termini of the chromosome may be recognized as double strand break. The telomeric sequence is added by a particular ribonucleoprotein complex called telomerase, identified by Elizabeth Blackburn and Carol Grieder. ${ }^{18-22}$

During replication, DNA replicating machinery cannot copy the single stranded region of the telomere, therefore the telomeres shorten with each cell division, by 50-200 bp. Interestingly, telomerase activity is low or absent in most human cells. ${ }^{20}$ So, when the telomeres reach a threshold length because of repeated cell division, checkpoint-mediated cellular senescence is initiated, pausing cell division, the Hayflick limit. As a result, telomere length may be considered as a mitotic clock to limit cell proliferation, thus, reflecting the course of aging. It has been widely believed that reactivation of telomerase activity and eventual lengthening of telomere can result in immortalization. This make telomere or telomerase an important research area in humankind quest for immortality. ${ }^{23}$ Another school of thought, contrastingly, believed that there is no basis for a general telomere or telomerase involvement in the hypothesis of aging. ${ }^{21}$

Anyhow, inappropriate activation of telom- 
erase allows unregulated cell growth, like cancer. In at least $85 \%$ of human cancers, telomerase reactivation has been seen and many cancer drugs target telomerase, although it was recently described that another pathway, telomeraseindependent alternative lengthening of telomere (ALT) pathway can maintain the length of telomeres. But this does not suggest that the activation of telomerase is all together bad. Insufficiency of telomerase can cause diseases like dyskeratosis congenita, aplastic anemia, and idiopathic pulmonary fibrosis $(\mathrm{T} 3, \mathrm{~T} 10,54) .{ }^{19,24,25}$

\section{Conclusion}

Different organisms have different life cycles. The manner and duration remain relatively diverse. Some manage to live for over a century, while others persisted only a day or two. The oldest known living thing in the world, a grampositive bacteria, Actinobacteria is estimated to be $\sim 400,000$ years old. Other species with long lasting lives include the great basin bristlecone spine (4,862 years), Antartic sponge $(1,550$ years), Bowhead whales (210 years), etc. ${ }^{3}$ But are they immortals? I'm afraid not. Our interest is not on long lasting lives but everlasting lives, like the beliefs of most religions. But just because these long living organisms can somehow die, we should not simply stop being curious in finding their secrets. At least we have to start somewhere, like the time we learn to build an airplane before we fly to the moon. Our discussion is somehow too short as we have to exclude other interesting biological immortals. But to mention all would be too extended. It may not be very wrong to focus on long living organisms, which are among the simplest life forms called basal metazoans, a group that includes sponges, corals, jellyfish, comb jellies, hydras, and sea anemones in our search for immortality. ${ }^{26,27}$

At the macroscopic level, nature has a tendency to screw up, an effect called entropy in physics. But, on a microscopic scale, since the amount of energy involved is very small, it is very difficult to know for certainty that the entropy increases, thus, the entropy effect might alto- gether be negligible. ${ }^{28}$ This might explain why nature has find a way of immortality at the cellular level but not on a multicellular organismal level, because once we became an organism, nature screwed us to expire. To put a butter to this bread, cell lines, like the HeLa cells can be frozen and thawed without killing them, but our current scientific, technological and ethical advancement cannot yet determine the method to replicate this resurrecting technique on a multicellular organismal scale. Do not get me wrong here. A North American frog Rana sylvatica during hibernation have their body frozen and can live normal lives after being thawed. But in these case, only around $70 \%$ of water in their body is frozen. ${ }^{29}$ A $100 \%$ frozen body might present a different story.

I believe the core concept of every religion is to live forever. Some believe in infinite spiritual life after the termination of our physical beings, while others believe in reincarnation. Some religions even believe in the existence of a herb of immortality. Some scholars have identified this herb as Amanita muscaria, a.k.a. Fly Agaric, a.k.a. Maga. ${ }^{30}$ Our yearning of immortality, echoing through the beliefs of many, if not all religions and cultures throughout ages, may one fine day be accomplished through the advancement of science and technology, or by nature. By then, humans will no longer be humans but a whole new species, perhaps Homo infinitus, capable of evading death and no longer having to procreate (life must be so dull), because procreation after attaining immortality will only lead to population explosion. But this process of speciation may take millions or billions of years, an incomprehensible process to many because of the inability or ignorance to incorporate the time factor involved. This rationale may possibly be that our mind does not evolve to think for period as millions or billions of years. Sadly, we may not have the time to evolve to immortals. Looking at the effects we have imprinted on the only known planet that can sustain life, this anthropocene period may be our last signature. 


\section{References}

I. Hayflick L (2000). The illusion of cell immortality. BrJ Cancer, 83, 84I-846.

2. Cegolon L, Heymann WC, Lange JH \& Mastrangelo G (2013). Jellyfish stings and their management: A review. Mar Drugs, II, 523-550; doi: I0.3390/mdiro20523.

3. $\mathrm{Ma} \mathrm{H} \&$ Yang $\mathrm{Y}$ (2010). Turritopsis nutricula. Nature and Science, 8, 15-20.

4. Schmich J, Kraus Y, De Vito D, Graziussi D, Boero F \& Piraino $S$ (2007). Induction of reverse development in two marine hydrozoans. Int J Dev Biol, 51, 45-56.

5. Piraino S, De Vito D, Schmich J, Bouillon J \& Boero F (2004). Reverse development in Cnidaria. Can J Zool, 82, I748-I754. Doi: Io.I139/Zo4-I74.

6. Jopling C, Boue S \& Belmonte CI (2OII). Dedifferentiation, transdifferentiation and reprogramming: three routes to regeneration. $\mathrm{Nat} \operatorname{Rev}$, I2, 79-89.

7. Piraino S, Boero F, Aeschbach A \& Schmid V (1996). Reversing the life cycle: Medusae transforming into polyps and cell trandifferentiation in Turriptosis nutricula (Cnidaria, Hydrozoa). Biol Bull, 190, 302-312.

8. Skloot $\mathrm{R}$ (20I0). The immortal life of Henrietta Lacks. Crown Publishers, a division of Random House, Inc., New York, pp. 15-357

9. Greely HT \& Cho MK (2013). The Henrietta Lacks legacy grows. EMBO Report, $\mathrm{I} 4,849$.

Io. Lucey BP, Nelson-Rees WA \& Hutchins GM (2009). Henrietta Lacks, HeLa cells, and cell culture contamination. Arch Pathol Lab Med, II3, I463-I467.

II. Ncayiyana DJ (20II). The extraordinary story of the life after death of Henrietta Lacks. $S$ Afr Med J, IOI, I4I.

I2. Hejmadi M (20IO). Defining cancer. In: Introduction to Cancer Biology, $2{ }^{\text {nd }}$ edition, bookboon.com, p. 7.

13. Mukherjee S (2010). The emperor of all maladies: A biography of cancer. Scribner, A division of Simon \& Schuster, Inc. I230 Avenue of the Americas, New York, NY Ioo2o, pp. 9-19I.

I4. Goldberg EE, Igic B (2008). On phylogenetic tests of irreversible evolution. Evol, 62, 2727-274I.
15. Hongboa M, Young M \& Yan Y (2014). Aging and senescence. Stem Cells, 5, 49-53.

16. Cech TR (200o). Life at the end of the chromosome: telomeres and telomerase. Angew Chem Int Ed, 39, 3443.

17. Finkel T, Serrano M \& Blasco MA (2007). The common biology of cancer and ageing. Nat, 448, 767-774.

18. Shawi M \& Autexier C (2008). Telomerase, senescence and ageing. Mechanism of Ageing and Development, I29, 3-IO.

19. Osterhage JL \& Friedman KL (2009). Chromosome end maintenance by telomerase. J Biol Chem, 284, 1606I16065 .

20. White LK, Wright WE \& Shay JW (200I). Telomerase inhibitors. Trends Biotechnol, 19, II4-I2O.

2I. Campisi J (200I). From cells to organisms: can we learn about aging from cells in culture? Exp Geront, 36, 607618.

22. Corey DR (2009). Telomeres and telomerase: From discovery to clinical trials. Chem Biol, I6, I219-I223.

23. Dahse R, Fiedler W \& Ernst G (1997). Telomeres and telomerase: biological and clinical importance. Clin Chem, 43, 5, 708-714.

24. Shay JW (1997). Telomerase in human development and cancer. J Cell Physio, 173, 266-270.

25. Durant ST (2012). Telomerase-independent paths to immortality in predictable cancer sub-types. $J$ Cancer, 3 , 67-82.

26. Petralia RS, Mattson MP \& Yao PJ (2014). Aging and longevity in the simplest animals and the quest for immortality. Ageing Res Rev, 16, 66-82.

27. Galliot B \& Schmid V (2002). Cnidarians as a model system for understanding evolution and regeneration. Int J Dev Biol, 46, 39-48.

28. Aquilano RO (201I). The asymmetry of time and the cellular world. Is immortality possible? JBPC, 2, I, 49-52.

29. Layne Jr JR \& Lee Jr RE (1995), Adaptations of frogs to survive freezing. Clim Res, 5, 53-59.

30. Teeter DE (2007). Amanita muscaria; Herb of immortality, Ambrosia Society, 4800 Yager Lane, Manor, Texas, 78653, pp. 13-15. 